\title{
TPACK-integrated Worked Examples for Technology Integration
}

\author{
Jiwak Raj Bajracharya, PhD \\ Program Coordinator, Master in Technical and Vocational Education and Training \\ Kathmandu University, School of Education, \\ Hattiban, Lalitpur, Nepal \\ Email for correspondence: jiwak@kusoed.edu.np
}

\begin{abstract}
The purpose of the study was to develop and validate the Worked Examples to enhance the instructors' competencies in carrying out technology integration during teaching and learning. Worked Examples in the study was developed based on the Gagne's Nine Event of Instruction, which is one of the classroom-oriented micro level Instructional Design Models. Technology integration in the study is defined as an implementation of technological resources and pedagogical strategies to deliver the required content knowledge during classroom instruction. Thus, Technological Pedagogical and Content Knowledge (TPACK) was integrated in the developed Worked Examples. Development and Design research design was implemented to develop and validate the Worked Examples, employing qualitative and quantitative data, where three instructors from Teacher Education Program utilized Worked Examples during their classroom instruction. Extraneous cognitive load of instructors found to be addressed because of employing Worked Examples. Furthermore, preservice teachers learning outcomes was also significantly improved because of instructors' instructions with Worked Examples.
\end{abstract}

Keywords: TPACK; Worked Examples; Technology Integration; Instructional Design Model

\section{Technology Integration}

As argued by numerous researchers and practitioners, technology integration has become an integral part of the educational system in the twenty-first century learning environment in the developed and developing countries (Clements \& Sarama, 2003; Haugland, 2005; McKenney \& Voogt, 2012; Parette \& Blum, 2013; Yelland, 2005). Kozma (2002, p.2) highlighted that increased utilization of "technology into classroom and curricula" is to improve educational systems and prepare the learners for the twenty-first century. Further, United National Educational, Scientific and Cultural Organization (UNESCO) has been providing technical assistance for the enhancement of instructors' competencies in the developing countries (UNESCO, 2008). These efforts from various stakeholders including national bodies, international organizations, and donor 
agencies were focused on enhancing the instructors' technical competencies for the utilization of technology in classroom instruction.

As reported by numerous studies, the utilization of technology in classroom instruction is crucial because technology opens up numerous opportunities, such as promoting teaching and learning effectiveness, addressing the teaching and learning load, making teaching and learning more flexible, and enhancing classroom interactions (Hall \& Higgins, 2005; Kennewell, 2001; Lopez, 2010, Smith, Higgins, Wall, \& Miller, 2005). Furthermore, technology supports learners to understand the subject matter (Taylor, Harlow, \& Forret, 2010) while enhancing their engagement in the classroom activities leading to purposeful learning (Jang, 2012). YouTube videos, educational blogs, social media, software, and applications, which encourage learners to think beyond the four walls of the classroom, play important roles in education to improve learning (Bajracharya, 2017; Gilory, 2010; Haddad \& Draxler, 2002). In addition, technology helps learners to be critical thinkers, communicators, collaborators, creators, and problem-solvers to eventually become effective and efficient citizens, workers, and future leaders of the nation (Cynthia, 2015). Technology in education, therefore, is important to improve teaching and learning in the twenty-first century society.

However, as Bitner and Bitner (2002), Gulbahar (2007), and Pierson (2001) mentioned for technology to be truly effective in education, appropriate technology integration in teaching and learning is essential. The U.S. Department of Education (2002, p.174) has defined the term technology integration as "the incorporation of technology resources and technology-based practices" into teaching and learning. As mentioned by Hunter (2015), an incorporation of technology resources refers to the use of technological tools in teaching and learning in general content areas. Further, technology-based practices serve to enhance instruction that also supports the learners' learning (Amy \& Katina, 2014;
Richard, 2009).

Meanwhile, Mishra and Koehler (2006) argued that technology integration is not about putting technological resources together and replacing the technical skills in regular classrooms to enhance the learners' learning. As noted by Norris, Shullivan, and Poirot (2003), the availability of technological tools and instructors' technical competencies could create the possibility of technology integration but their competencies in creating a technology-integrated instruction by implementing pedagogical strategies for the content are also crucial for carrying out technology integration. Therefore, technological resources and instructors' technical competencies could not be enough for bringing technology integration during classroom instruction.

\section{Technological Pedagogical and Content Knowledge (TPACK)}

Recent developments in the field of educational technology have led to a renewed interest in considering the three specific elements in technology integration consisting of Technology, Pedagogy, and Content as specified by Koehler and Mishra (2005). Further, Mishra and Koehler (2006) organized those elements into three major areas of knowledge including Technological Knowledge, Pedagogical Knowledge, and Content Knowledge required by instructors for technology integration, which is termed as Technological Pedagogical and Content Knowledge (TPACK). TPACK is a conceptual framework that builds on Shulman's (1986, p.12) theoretical basis of Pedagogical Content Knowledge (PCK) referring to the "instructors' understanding of technologies and PCK" for bringing technology integration in the classroom instruction (Koehler \& Mishra, 2008; Mecoli, 2013). A TPACK framework addresses the complexity of teaching by integrating technologies and pedagogical strategies simultaneously to deliver the required content during classroom instruction, which focuses on the enhancement of instructors' competencies for technology integration (Bajracharya, 2015; Mishra \& Koehler, 2006; Mishra \& Koehler, 2009; Mishra, 
Koehler, \& Kereluik, 2009). Thus, in the study, technology integration is defined as an implementation of technological resources and pedagogical strategies to deliver the required content knowledge during classroom instruction.

\section{Barriers to Technology Integration}

As found by Hunter (2015, p.5), technology integration "is not easy" because many instructors prefer to simply add technological tools to the classroom, for example by utilizing word processing for literacy tasks and Excel spreadsheets for entering numerical data without considering its effects on learners' learning experiences. In addition, Dockstader (1999, p.73) argued that the substitution of 30 minutes of reading with 30 minutes of computer skill development is a poor example of technology integration. All these studies reveal that the act of technology integration into teaching and learning is a complex process hindered by several barriers. Brickner (1995), Ertmer (1999), and Tsai and Chai (2012) discussed three types of barriers to technology integration, such as first-order, second-order, and third-order barriers. The first-order barrier is an external factor that includes lack of adequate resources, time, training, and institutional support. The second-order barrier is related to personal beliefs which is more instructor-centered relating to instructors' attitudes toward technology integration. These attitudes consist of the instructors' self-efficacy toward technology integration and attitude toward technology. The second-order barriers are the main causes for the instructors' willingness to adopt technology in education in the first place. The thirdorder barrier refers to instructors' competency in creating a technology-integrated lesson plan for the classroom instruction. It is associated with the utilization of technological resources with appropriate pedagogical strategies to deliver the content during classroom instruction.

As argued by the number of authors, even if the firstorder and second-order barriers are resolved, technology integration may not necessarily proceed naturally without addressing the third-order barriers which are associated with the instructors' competencies for creating technology-integrated lesson plans (Albirini, 2006; Almekhlafi \& Almeqhadi, 2010; Goktas, Yildirim, \& Yildirim, 2009; Lim \& Chai, 2008; Lim \& Pannen, 2012; Tsai $\&$ Chai, 2012). In particular, Jhurree (2005) argued that instructors from developing countries possess a high level of apprehension to integrate technology in the classroom because they lack the necessary competencies to create a technology-integrated lesson plan, even if they possess high levels of technical knowledge. This shows that the instructors' competencies for creating a technology-integrated lesson plan are crucial for implementing technology integration in the classroom.

In the context of Nepal, Karmacharya (2015) reported that Nepalese instructors require a lot of continuous guidance and support to integrate technology while delivering instruction, even if they were willing to practicing technology integration in the classroom. The finding was based on a mega project named Open Learning Exchange Nepal (OLE-Nepal) which was conducted in 26 academic institutions across six districts of Nepal. During the training period of the project, instructors were trained to enhance their technical competencies and were provided with the required technological resources for carrying out technology integration. This evidence highlighted that even if Nepalese instructors possess the technological resources, training, and willingness, which are necessary for technology integration in the classroom, their low level of competencies to create a technology-integrated lesson plan are need to be addressed. Further, Wagle (2013) emphasized that technology needs to be used as an effective instructional tool by instructors for enhancing the learners' learning, which should not be limited to simply enhancing the instructors' technical competencies.

\section{Existing Issues}

The above discussions suggest that a developing country like Nepal may need further detailed guidance for instructors in creating and implementing 
technology-integrated instructions regardless of their technical competencies. Studies done by Bauer and Kenton (2005) and Mishra and Koehler (2006) also highlighted that instructors' high level of technical competencies are not enough for technology integration. Thus, in a developing country like Nepal where efforts have been prioritized to provide technological resources and skill-based trainings to enhance instructors' technical competencies with the aid of international agencies, there is a need to urgently consider an applicable way to assist instructors in creating and implementing technologyintegrated instructions for carrying out technology integration in the classroom.

Studies revealed that developing countries suffer considerably from the first-order barriers to technology integration (technological infrastructures and trainings) because of issues related to national policies and funding, which are beyond the control of most instructors (Jhurree, 2005; Khan, Hossain, Hasan, \& Clement, 2012). However, as discussed above in the Nepalese context, third-order barrier: creating a technology-integrated instruction is hurdle to technology integration in the classroom instruction, which is termed as the instructors' competencies in the study (the term instructors ' competencies is used throughout the study in the place of the instructors' knowledge and skills to create technology-integrated instructions).

Numerous studies revealed that instructors' competencies for technology integration could be improved with an appropriate technology integration model in a Teacher Education Program to train preservice teachers (Dawson, 2008; Kirschner \& Selinger, 2003; Stuart \& Thurlow, 2000; Tearle \& Golder, 2008; Tondeur, van Braak, Sang, Voogt, Fisser, \& Ottenbreit-Leftwich, 2012). A study done by Stuart and Thurlow (2000) argued that pre-service teachers need to be adequately trained for assisting instructors to carry out technology integration. Further, Hare, Howard, and Pope (2002, p.193) conducted a study with 26 pre-service teachers to examine a gap between what pre-service teachers are taught about the technology integration and how they could implement those competencies to teach in the classroom. The authors found that the preservice teachers trained with technology-integrated instructions had a high level of beliefs and confidence to integrate technology in the classroom instruction compared with those pre-service teachers who were trained under as usual instruction.

As discussed by Chai, Koh, and Tsai (2010), Niess (2005), Tondeur, Pareja Roblin, van Braak, Voogt, and Prestridge (2017), Teacher Education Program is a platform to educate future instructors to enhance the willingness as well as a competency that required for carrying out technology integration in the classroom instruction. Among which, Teacher Education program also appears to be crucial for enhancing positive attitudes toward technology integration (Shirvani, 2014; Wang, Ertmer, \& Newby, 2004).

Studies done by Lee (2014), and Lee and Sparks (2014) in the Nepalese context, argued that even if Nepalese instructors had access to mobile phones, computers, and digital cameras, there are continued hurdles for technology integration. Based on the focus group interview with 27 Nepalese instructors and follow-up of individual interviews, the authors found that the instructors lacked enough competencies to create a technology-integrated lesson plan for classroom instruction. Therefore, the authors suggested that the availability of detailed guidance could assist instructors to create and implement technology-integrated instructions, which could bring a significant improvement in carrying out technology integration. Similarly, Khan, Hossain, Hasan, and Clement (2012) also revealed that the instructors of developing countries require detailed structure in accomplishing the procedures that assist them to create technology-integrated instructions.

Carlson and Gadio (2002) argued that instructors could experience an extraneous cognitive load because of lacking detailed guidance in creating and implementing technology-integrated instructions 
based on the available models and framework [existing Instructional Design (ID) models, Substitution, Augmentation, Modification, and Redefinition (SMAR) model, TPACK framework, and TPACK-based instructional design models) for technology integration. van Merrienboer and Sweller (2005) found that an extraneous cognitive load could be alleviated by effective instructional interventions. One idea from a study done by Saravanan and Nagadeeps (2017) in India recommended that the extraneous cognitive load could be minimized by offering scaffolding process with Worked Examples for instructors.

\section{Worked Examples}

Worked Examples are a kind of scaffolding consisting of a detailed set of guidelines for instructors to accomplish a task based on a demonstration (Atkinson, Derry, Renkl, \& Wortham, 2000). As mentioned by Ayres and Sweller (2000), Worked Examples assist by addressing an extraneous cognitive load. Further, a study done by Mayer and Moreno (2003) suggested that Worked Examples are effective instructional strategies for addressing an extraneous cognitive load that deals with learning and problem-solving difficulties. Even more, recently Chen, Woolcott, and Sweller (2017) recommended that Worked Examples are the strategies to minimize an extraneous cognitive load.

Recently, Saravanan and Nagadeeps (2017) conducted a study in India in a Teacher Education Program with instructors and pre-service teachers to explore the barriers in technology integration. The authors found that the instructors had experienced an extraneous cognitive load during technology integration because they had to spend additional time to create a technology-integrated lesson plan. However, based on the findings of the study, most of the pre-service teachers benefited from technologyintegrated instructions having high engagement within the classroom. Thus, the authors suggested that Worked Examples could be an effective instructional strategy for addressing instructors' extraneous cognitive load that could occur while creating and implementing technology-integrated instructions by providing step-by-step instructional demonstration of a skill or a task performance.

The problem which initiated this study was the need for a Worked Examples to consider three key elements of technology integration as: content, pedagogy, and technology based on a systems thinking approach within a generic micro level instructional design process to assist instructors in creating and implementing technology-integrated instructions for carrying-out technology integration during the classroom instruction.

In this study, Worked Examples was developed based on a Gagne's Nine Events of Instruction includes nine steps from attention to retention and transfer (Solanki, 2014), which is a class-room oriented Instructional Design Model to create a technologyintegrated lesson plan. Thus, it is necessary to investigate how instructors in a Teacher Education Program could utilize a Worked Examples for technology integration in the classroom instruction. Further investigation needs to be carried out to understand the changes that could be found in the learning experiences of pre-service teachers because of technology-integrated instructions carried out by instructors based on a Worked Examples.

\section{Instructional Design}

ID is a procedure for developing an educational or training program, curricula, or courses in a sequential and authentic manner (Branch \& Merrill, 2011, p. 8). This procedure enables instructors to create a lesson plan that involves the "systematic planning of instruction" (Smith \& Ragan, 2005, p.8), ranging from instructional analysis to evaluation (Mager, 1984). It can also be referred to as a "systematic and reflective process of translating principles of learning and instruction into plans for instructional materials, activities, information resources, and evaluation" (Smith \& Ragan, 2005, p.4). These definitions explored that ID is a framework which provides the process to create the instructions based on the necessity of a teaching and learning environment. 
Thus, ID can be defined as a process to develop directions and specifications using learning and instructional theory to ensure the quality of instruction.

ID has also been perceived as both a science and an art to creating instructions from the planning to the evaluation stages in which revisions can be made after implementation of the program (Carr-Chellman \& Reigeluth, 2009, pp. 5-9). Science and the arts are both core concepts of ID and are useful in creating and implementing instruction, a complicated process involving human ingenuity, software and hardware components (Piskurich, 2006, p.3). Essentially, ID is all about a set of rules constituting a chronological process. For instance, development of a training program involves a series of methods such as analyzing, designing, developing, implementing, and evaluating to create quality learning experiences and environments. In summary, the primary goal of the ID process is to generate the instruction to achieve the objectives of the program and training.

\section{Creating a Technology-integrated Lesson Plan through Worked Examples}

As discussed above, Worked Examples were provided to instructors to create a technology-integrated lesson plan, Worked Examples were offered to the three instructors. Explanation under technology integration was carried out based on the triangulating source of information such as: classroom observations, interviews, and reflective journals as described below:

Technology integration. Classroom observations revealed that the instructors utilized Worked Examples for indexing specific information a topic of a lesson, pre-service teachers need to learn, and pre-service teachers need to understand at an end of the classroom instruction. It was also confirmed by the reflective journals that all the instructors had developed their lesson plans and detailed notes about content, pedagogy, and technology. Since detailed guidance was provided in the Worked Examples, instructors had utilized the various pedagogies and technologies presented to gain attention and inform objectives, to recall and present the content, to perform and gather feedback, and to enhance retention transfer.

Interviews with the instructors clarified that based on the detailed information about content, pedagogy, and they had designed and developed a technologyintegrated lesson plan. Instructor-1 mentioned that "Since detailed guidance with a key purpose was provided, I had followed those guides to develop a technology-integrated lesson plan. Further, based on that plan, I created a required material for classroom instruction" (Interview, Instructor-1).

The above statement of instructor- 1 clarifies that Worked Examples provided the detailed guidance to integrate content, pedagogy, and technology for a technology-integrated lesson plan. Similarly, Instructor-2 further added:

"I just followed the Worked Examples to design and develop a technology-integrated lesson plan; however, sometimes I was unable to follow all the detailed guidance because I found it was too much" (Interview, Instructor-2).

An interview with instructor- 2 revealed that even if Worked Examples were self-guided instructions, the instructors might not cover all the detailed guidance. However, Instructor-3 revealed that

"I just follow" For a technical instructor like me, this type of Worked Examples is very helpful that provide detailed guidance (Interview, Instructor 3).

Based on the above evidences, it was clarified that Worked Examples provided a detailed guidance which helped the instructors to design and develop a technology-integrated lesson plan.

Further, based on the interviews with three instructors, even if, they had practiced a technology-integrated lesson plan in the past, they still lacked the competencies needed to create a technology- 
integrated lesson and materials for classroom instruction. For example, Instructor-1 mentioned that

"Previously, I had used videos during classroom instruction to enhance the understanding level of pre-service teachers in terms of the contents, but I was not sure whether they were perceiving knowledge or not. However, Worked Examples to create a technology-integrated lesson and materials helps me to consider content, pedagogy, and technology simultaneously, which enhance the engagement level of pre-service teachers in the classroom instructions, further, it confirms their perceived knowledge too" (Interview, Instructor-1).

The above statement by instructor- 1 justifies that, the pedagogical strategies were not practiced previously to deliver a technology-integrated classroom instruction. The Worked Examples offered to the instructor-1, helped him to consider the content, pedagogy, and technology for carrying out technology integration. Further, it also assisted the pre-service teachers to internalize the delivered instructions. Similarly, instructor- 2 added that

"Even if, I am aware of the potential of technology integration, however, I was afraid of using technologies during classroom instruction because of my low technical ability. In the past, I always have to request my colleagues for assisting in delivering a technology-integrated lesson. However, I became surprised by knowing smartphones could enhance vocabulary of pre service teachers and Facebook for sharing the opinions. I must have to say that it allows me a freedom to select my desired technologies" (Interview, Instructor-2).

The instructors' reflections show that Worked Examples provide the freedom for instructors to select the appropriate technologies. Furthermore, Instructor-3 revealed that
"I used to teach technical subjects that modify often in terms of applications, software versions, and hardware tools. Worked Examples provide a roadmap to consider various instructional strategies to deliver required contents. However, even various pedagogical strategies could be considered but I was unable to utilize pedagogies in my classroom" (Interview, Instructor-3).

Reflection by Instructor-3 revealed that Worked Examples could be much more profitable in a technical subject compared with non-technical subjects. Based on the classroom observations, it could be further elaborated that classroom instruction based on the Worked Examples provide a technologyintegrated instruction in terms of content, pedagogy, and technology compared with the classroom instruction that was based on the typical instruction used previously.

\section{Pre-service Teachers' Learning Outcomes}

Learning outcomes of pre-service teachers were investigated based on their level of perceived knowledge and paper-based test. To achieve this, three instructors (In the study 3 cases was understood as class delivered by 3 instructors) divide their regular classes into two groups: treatment and control group based on random sampling for three weeks (18 class lectures), where treatment group of pre-service teachers were taught via Worked Examples and control group of pre-service teachers were taught via as usual instructions. The pretest and posttest were similar test instruments for perceived knowledge, which is adapted by Bajracharya (2015). It consisted of 33 items, which were on scale from one to five from strongly disagree as 1 and strongly agree as 5 .

\section{Pre-service teachers' perceived knowledge.}

Table 1 shows the mean (M) and standard deviation (SD) of all three cases. 
Table 1

Mean (M) and Standard Deviation (SD) of Pretest and Posttest for Treatment and Control Groups (N=28)

\begin{tabular}{llcccc}
\hline & & Pretest & Posttest & \\
\hline Cases & & $\mathrm{M}$ & SD & M & SD \\
\hline \multirow{3}{*}{1} & Treatment $(\mathrm{n}=14)$ & 3.00 & .555 & 3.64 & .497 \\
\hline \multirow{3}{*}{2} & Control $(\mathrm{n}=14)$ & 2.71 & .469 & 2.86 & .143 \\
\hline \multirow{3}{*}{3} & Treatment $(\mathrm{n}=14)$ & 3.43 & .514 & 3.93 & .267 \\
& Control $(\mathrm{n}=14)$ & 3.93 & .267 & 4.07 & .267 \\
\hline
\end{tabular}

Table 2 represents a paired $t$ test analysis of the three cases. In Case 1, significant differences were not found in the scores between the treatment group $(\mathrm{M}=3.00, \mathrm{SD}=.555)$ and control group $(\mathrm{M}=2.71$, $\mathrm{SD}=.469), t(13)=1.749, p=0.104, d=0.47$. The effect size of this analysis was Cohen's $d=0.47$ and was found to be a small effect $d=0.20$. These results suggest that there were no differences in learning outcomes in the pretest between the treatment and control groups. The results also indicate that both the treatment and control groups were equal in ability for learning outcomes before a classroom instruction with a technology-integrated lesson plan based on a Worked Examples (the term intervention is used throughout the chapter in the place of classroom instruction with a technology-integrated lesson plan based on a Worked Examples).

However, statistical significance was found in the test scores of the pretest $(\mathrm{M}=3.00, \mathrm{SD}=0.555)$ to posttest $(\mathrm{M}=3.64, \mathrm{SD}=0.497), t(13)=-3.798$, $p=.002, d=1.01$. The effect size for this analysis was Cohen's $d=1.01$ and was found to exceed Cohen's (1988) convention for a large effect $(d=0.80)$. These results suggest that the pre-service teachers in the treatment group performed significantly better in the posttest than in the pretest. It also indicates that the treatment group which gained classroom instruction based on an intervention was large in effect size. Further, the pretest and posttest for the control group were compared as pair 2 . The analysis shows that there was no statistically significant difference in the scores for the pretest $(\mathrm{M}=2.71, \mathrm{SD}=0.469)$ and posttest $(\mathrm{M}=2.86, \mathrm{SD}$ $=0.143), t(13)=-1.472, p=0.165, d=0.39$. The size for this analysis was Cohen's $d=0.39$ and was found as a small effect $(d=0.20)$. These results suggest that the effect of the perceived knowledge was also small.

\section{Table 2}

Paired $t$ Test of Pretest and Posttest of Treatment and Control Groups (N=28)

\begin{tabular}{|c|c|c|c|c|c|c|c|c|c|c|}
\hline \multicolumn{11}{|c|}{ Paired t test } \\
\hline \multirow{2}{*}{\multicolumn{2}{|c|}{ Cases }} & & \multirow[t]{2}{*}{ Mean } & \multirow[t]{2}{*}{$\begin{array}{c}\text { Std. } \\
\text { Deviation }\end{array}$} & \multirow{2}{*}{$\begin{array}{l}\text { Std. } \\
\text { Error } \\
\text { Mean }\end{array}$} & \multicolumn{2}{|c|}{$\begin{array}{c}95 \% \text { Confidence Interval of } \\
\text { the Difference }\end{array}$} & \multirow[t]{2}{*}{$\mathrm{T}$} & \multirow[t]{2}{*}{$\mathrm{df}$} & \multirow{2}{*}{$\begin{array}{l}\text { Sig. } \\
\text { (2-tailed) }\end{array}$} \\
\hline & & & & & & Lower & Upper & & & \\
\hline \multirow{3}{*}{1} & Pair & $\begin{array}{l}\text { Pretest-treatment- } \\
\text { pretest-control }\end{array}$ & -.286 & .611 & .163 & -.067 & .639 & 1.749 & 13 & .104 \\
\hline & Pair1 & $\begin{array}{l}\text { Pretest-treatment- } \\
\text { posttest-treatment }\end{array}$ & -.643 & .633 & .169 & -1.009 & -.277 & -3.798 & 13 & $.002 * *$ \\
\hline & Pair2 & $\begin{array}{l}\text { Pretest-control- } \\
\text { posttest-control }\end{array}$ & -.143 & .363 & .097 & -.353 & -067 & -1.472 & 13 & .165 \\
\hline
\end{tabular}




\begin{tabular}{|c|c|c|c|c|c|c|c|c|c|c|}
\hline \multirow{2}{*}{2} & Pair1 & $\begin{array}{l}\text { Pretest-treatment- } \\
\text { posttest-treatment }\end{array}$ & -.500 & .519 & .139 & -.800 & -.200 & -3.606 & 13 & $.003^{* *}$ \\
\hline & Pair2 & $\begin{array}{l}\text { Pretest-control- } \\
\text { posttest-control }\end{array}$ & .143 & .363 & .097 & -.353 & .067 & -1.472 & 13 & .165 \\
\hline 3 & Pair1 & $\begin{array}{l}\text { Pretest-treatment- } \\
\text { posttest-treatment }\end{array}$ & -.286 & .611 & .163 & -.639 & .067 & -1.749 & 13 & .104 \\
\hline & Pair2 & $\begin{array}{l}\text { Pretest-control- } \\
\text { posttest-control }\end{array}$ & -.143 & .663 & .177 & -.526 & .240 & -.806 & 13 & .435 \\
\hline
\end{tabular}

In Case 2, the pretest score of the treatment group $(\mathrm{M}=3.43, \mathrm{SD}=0.514)$ to posttest $(\mathrm{M}=3.93, \mathrm{SD}$ $=0.267), \mathrm{t}(13)=-3.606, \mathrm{p}=0.003, \mathrm{~d}=0.96$ revealed that there was a statistically significant difference with a large effect compared to the pretest score of the control group $(\mathrm{M}=3.93, \mathrm{SD}=0.267)$ to posttest $(\mathrm{M}=4.07, \mathrm{SD}=0.267), \mathrm{t}(13)=-1.472, \mathrm{p}-7=0.165$, $\mathrm{d}=0.39$, which showed that there was no significant difference and effect size was also small. Their findings show that an intervention could bring a huge change in perceived knowledge of pre-service teachers.

Similarly, in Case 2, the pretest score shows that there was no statistical difference in the test scores from the pretest $(\mathrm{M}=3.64, \mathrm{SD}=0.497)$ to posttest $(\mathrm{M}=3.93, \mathrm{SD}=0.469), \mathrm{t}(13)=-1.749, \mathrm{p}=0.104$, $\mathrm{d}=0.46$ in treatment group, and test scores from the pretest $(\mathrm{M}=3.71, \mathrm{SD}=0.469)$ to posttest $(\mathrm{M}=3.86$, $\mathrm{SD}=0.535), \mathrm{t}(13)=-0.806, \mathrm{p}=0.435, \mathrm{~d}=0.21$. The effect size revealed that even if the differences were not found to be statistically significant, the level of knowledge perceived by treatment group was high.
Pre-service teachers' paper-based test. The study involved three different cases and the mean scores of the paper-based test of Cases 1,2 and 3 were measured to identify the specific content knowledge of the PST among the treatment and control groups. Table 4.3 represents the paper-based test scores; PST in the treatment group secured higher test scores in the posttests compared to that of the pretests. For instance, PST from the control treatment group scored $10 \%$ (pretest) to $67 \%$ (posttest) in Case 1 , $15 \%$ (pretest) to $78 \%$ (posttest) in Case 2 and $18 \%$ (pretest) to $61 \%$ (posttest) in Case 3 .

Accordingly, the increase in test scores was also found in the control group of PST. For example: $15 \%$ (pretest) to $31 \%$ (posttest) in Case $1 ; 19 \%$ (pretest) to $43 \%$ (posttest) in Case 2; and 19\% (pretest) to $51 \%$ (posttest) in Case 3. These results indicate that the PST under the treatment group appeared to perform better than that of the control group. These findings justify that the pre-service teachers had performed better with an instructors' instruction with Worked Examples.

Table 3

\section{Paper-based Test Scores}

\begin{tabular}{lllll}
\hline Cases & \multicolumn{2}{c}{ Treatment group } & \multicolumn{2}{c}{ Control group } \\
\cline { 2 - 5 } & Pretest (\%) & Posttest (\%) & Pretest (\%) & Posttest (\%) \\
\hline 1 & 10 & 67 & 15 & 31 \\
2 & 15 & 78 & 19 & 43 \\
3 & 18 & 61 & 19 & 51 \\
\hline
\end{tabular}

\section{Discussions and Conclusions}

This study attempted to develop and validate a Worked Examples to assist instructors in creating a technology-integrated lesson plan by providing the set of guidelines (Appendix A) to address an extraneous cognitive load of instructors.

Several studies suggest that Worked Examples is an 
effective instructional strategy to explain the several steps for novices (Clark, Nguyen, Sweller, 2006; Renkl, 2005; Salden, Aleven, Schwonke, Renkl, 2008). In the present study, Worked Examples were offered to assist instructors for creating technologyintegrated lessons, found to be very effective as selfguided instructions. This finding reinforces the belief of Chi, Bassok, Lewis, Reimann, and Glaser (1989) and Kalyuga, Chandler, and Sweller (2000) that highlighted the idea that Worked Examples actively explained how to accomplish the tasks. Even more, Renkl (2005) added that both active and passive instructors need to be active with self-paced instructions such as Worked Examples in addressing an extraneous cognitive load.

The present study revealed that Worked Examples with various chunks in terms of key phases and key components assist instructors in creating technologyintegrated lessons in carrying out technology integration during classroom instruction. As highlighted by Alber (2011), providing support by breaking information into the chunks is a crucial step for achieving concrete structure. The process of breaking such instructions into the chunks is termed as scaffolding (Alber, 2011). This concept was initially carried out by Wood, Bruner, and Ross (1976) in learning, who define it as a process to enable a novice in achieving a goal via self-guided instructions.

Furthermore, the study revealed that Worked Examples also save time in creating technologyintegrated lessons, even for instructors with low technological competencies. The study done by Bauer and Kenton (2005) highlighted that instructors were not carrying out technology integration even if they were highly educated, skilled with technology and capable of overcoming obstacles because they still needed extra time for creating technologyintegrated lessons. Thus Worked Examples can assist in carrying out technology integration.

As highlighted by Renkl (2005), Worked Examples consist of a well-structured step in accomplishing the final goal. Even more, Van Gog, Kester and Paas (2011) revealed that instructors can develop their skills to produce several strategies based on a wellstructured step provided by Worked Examples. In the present study, findings from observations revealed that instructors design and develop the technologyintegrated lessons/ and materials simultaneously instead of accomplishing in two phases as prescribed by Worked Examples. In addition, findings from the interviews also revealed that the present study provided Worked Examples having the integration of texts and diagrams assisted instructors to bring out such strategies, which was also found by Tabbers, Martens, and van Merriënboer (2000) and highlighted that such integration of text and diagrams are the key characteristics of an effective Worked Examples.

\section{References}

Alber, R. (2011). Six scaffolding strategies to use with your students. Teacher Leadership, 30, 45 50.

Albirini, A. (2006). Teachers' attitudes toward information and communication technologies: The case of Syrian EFL teachers. Computers and Education, 47(4), 373-398. doi: https://doi.org/10.1016/j.compedu.2004.10.013

Almekhlafi, A. G., \& Almeqdadi, F. A. (2010). Teachers' perceptions of technology integration in the United Arab Emirates school classrooms. Journal of Educational Technology and Society, 13(1), 165-175.

Amy, L.S. \& Katina, M.L. (2014). The impact of technology on PK-12 teacher preparation programs. In V. Wang (Ed.), Handbook of research on education and technology in a changing society (pp. 235-245). Hershey, PA: Information Science Reference.

Atkinson, R. K., Derry, S. J., Renkl, A., \& Wortham, D. (2000). Learning from examples: Instructional principles from the worked examples research. Review of Educational Research, 70(2), 181 214. 
Ayres, P., \& Sweller, J. (2005). The split-attention principle in multimedia learning. In R. Mayer (Ed.), Cambridge handbook of multimedia learning (pp. 135-146). Cambridge: Cambridge University Press.

Bajracharya, J.R. (2015). TPACK Survey for Nepalese preservice teachers. Paper presented at the 19th International Conference on Education Researh, Seoul, South Korea. Abstract retrived on August 24, 2016, from http: www.icer.snu. ac.kr/contents/Down_Session2.asp

Bajracharya, J.R. (2017). Strength of traditional and social media in education: A review of the literature. Journal of Research and Methods in Education, 6(6), 13-21.

Bauer, J., \& Kenton, J. (2005). Toward technology integration in the schools: Why it isn't happening. Journal of Technology and Teacher Education, 13(4), 519-546.

Bitner, N. \& Bitner, J. (2002). Integrating technology into the classroom: Eight keys to success. Journal of Technology and Teacher Education, 10(1), 95-100.

Branch, R., \& Merrill, M. D. (2011). Characteristics of instructional design models. In R. Reiser \& J. Dempsey (Eds.), Trends and issues in instructional design and technology $\left(3^{\text {rd }} \mathrm{ed}\right.$.) (pp.8-17). Upper Saddle River, NJ: Merrill Prentice Hall.

Brickner, D. L. (1995). The effects of first and second order barriers to change on the degree and nature of computer usage of mathematics teachers: A case study. Unpublished doctoral dissertation, Purdue University, West Lafayette.

Carlson, S., \& Gadio, C. T. (2002). Teacher professional development in the use of technology. In W. Haddad \& A. Draxler (Eds.), Technologies for education (pp.118-132). UNESCO: Paris.
Carr-Chellman, A. A., \& Reigeluth, M. C. (2009). Understanding the Instructional Theory. In C. Reigeluth \& A. Carr-Chellman (Eds.), Instructional design theories and models: Building a common knowledge base (3rd ed.) (pp. 3-26). New York, NY: Routledge.

Chai, C. S., Koh, J. H. L., \& Tsai, C. C. (2010). Facilitating preservice teachers' development of technological, pedagogical, and content knowledge (TPACK). Educational Technology and Society, 13(4), 63-73.

Chi, M. T., Bassok, M., Lewis, M. W., Reimann, P., \& Glaser, R. (1989). Self-explanations: How students study and use examples in learning to solve problems. Cognitive science, 13(2), 145 182.

Chen, O., Woolcott, G., \& Sweller, J. (2017). Using cognitive load theory to structure computer-based learning including MOOCs. Journal of Computer Assisted Learning, 33(4), 293-305. doi: 10.1111/jcal.12188.

Clark, R. C., Nguyen, F., \& Sweller, J. (2011). Efficiency in learning: Evidence-based guidelines to manage cognitive load. San Francisco, CA: John Wiley \& Sons.

Clements, D., \& Sarama, J. (2003). Strip mining for gold: Research and policy in educational technology-A response to 'Fool's Gold'. Educational Technology Review, 11(1), 7-69.

Cynthia, L. S. (2015). The Future of Learning 3: What kind of pedagogies for the 21st century? Retrieved on October 25, 2017, from http://unesdoc.unesco.org/images/0024/ 002431/243126e.pdf

Dawson, V. (2008). Use of information communication technology by early career science teachers in Western Australia. International Journal of Science Education, 30(2), 203-219. 
Dockstader, J. (1999). Teachers of the 21 st century know the what, why, and how of technology integration. Technological Horizons in Education Journal, 26(6), 73-74.

Ertmer, P. A. (1999). Addressing first- and second order barriers to change: Strategies for technology integration. Educational Technology Research and Development, 47(4), 47-61.

Goktas, Y., Yildirim, S., \& Yildirim, Z. (2009). Main barriers and possible enablers of ICTs integration into pre-service teacher education programs. Journal of Educational Technology and Society, 12(1), 193-204.

Gulbahar, Y. (2007). Technology planning: A roadmap to successful technology integration in schools. Computers and Education, 49(4), 943-956. doi: https://doi.org/10.1016/j.compedu.2005.12.002

Haddad, W. D., \& Draxler, A. (2002). Technologies for Education: Potential, Parameters, and Prospects. UNESCO, Paris. Retrieved on January 17, 2016, from http://unesdoc.unesco.org/images /0011/001191/119129e.pdf

Hall, I., \& Higgins, S. (2005). Primary school students' perceptions of interactive whiteboards. Journal of Computer Assisted Learning, 21(2), 102-117.

Hare, S., Howard, E., \& Pope, M. (2002). Technology integration: Closing the gap between what preservice teachers are taught to do and what they can do. Journal of Technology and Teacher Education, 10(2), 191-203.

Haugland, S. (2005). Selecting or upgrading software and web sites in the classroom. Early Childhood Education Journal, 32(5), 329-340.

Hunter, J. (2015). Technology integration and high possibility classrooms. New York, NY: Routledge.

Jang, S. J. (2012). From PCK to TPACK: Research and development. New York, NY: Nova Science
Publishers, Inc.

Jhurree, V. (2005). Technology integration in education in developing countries: Guidelines to policy makers. International Education Journal, 6(4), 467-483.

Karmacharya, R. (2015). Integration of technology in Nepali Classrooms: Lessons learned and future directions. Retrieved on August 16, 2016, from http://siteresources.worldbank.org/ EDUCATION/Resources/BBL-NepalOLE Karmacharya-4Aug2015.pdf

Kalyuga, S., Chandler, P., \& Sweller, J. (2000). Incorporating learner experience into the design of multimedia instruction. Journal of Educational Psychology, 92, 126-136.

Kennewell, S. (2001). Using affordances and constraints to evaluate the use of ICT in teaching and learning, Journal of Information Technology for Teacher Education, 10(1-2), 101-116.

Khan, M., Hossain, S., Hasan, M., \& Clement, C. K. (2012). Barriers to the introduction of ICT into education in developing countries: The example of Bangladesh. International Journal of Instruction, 5(2), 61-80.

Kirschner, P., \& Selinger, M. (2003). The state of affairs of teacher education with respect to information and communications technology. Technology, Pedagogy and Education, 12(1), 5 17.doi: $10.1080 / 14759390300200143$

Koehler, M. J., \& Mishra, P. (2005). Teachers learning technology by design. Journal of Computing in Teacher Education, 21(3), 94-102.

Koehler, M. J., \& Mishra, P. (2008). Introducing TPCK. In M.J. Koehler \& P. Mishra (Eds.), Handbook of technological pedagogical content knowledge for educators (pp 3-29). New York, NY: Routledge. 
Kozma, R. B. (2002). ICT and educational reform in developed and developing countries. CA: SRI International.

Solanki, M.R. (2014). Developing instructional multimedia module incorporating Gagne's Nine Events of Instruction. The Journal of Education, 2(1), 1-16.

Lee, J. (2014). "Technology Integration Challenges for Teachers in Nepal" Paper presented at the annual meeting of the Comparative and International Education Society Annual Conference, Sheraton Centre Toronto, Toronto, Ontario, Canada.

Lee, J. C. Y., \& Sparks, P. (2014). Three hurdles to technology integration: A case study of technology integration in Bungamati. Journal of Nepal English Language Teachers' Association, 18(1-2), 105-114. doi: http://dx.doi.org/10.3126 /nelta.v18i1-2.10334

Lim, C.P. \& Chai, C.S. (2008). Rethinking classroom - oriented instructional development models to mediate instructional planning in technology enhanced environments. Teaching and Teacher Education 24(8), 2002-2013.

Lim, C. P. \& Pannen, P. (2012). Building the capacity of Indonesian education universities for ICT in pre-service teacher education: A case study of a strategic planning exercise. Australasian Journal of Educational Technology, 28(6), 1061-1067.

Lopez, O. S. (2010). The digital learning classroom: Improving english language learners' academic success in mathematics and reading using interactive whiteboard technology. Computers and Education, 54(4), 901-915.

Mager, R. F. (1984). Measuring instructional results: Got a match. Belmont, CA: Pitman Publishing.

Mayer, R. E., \& Moreno, R. (2003). Nine ways to reduce cognitive load in multimedia learning. Educational Psychologist, 38(1), 43-52.
McKenney, S., \& Voogt, J. (2012). Teacher design of technology for emergent literacy: An explorative feasibility study. Australasian Journal of Early Childhood, 37(1), 4-12.

Mecoli, S. (2013). The influence of the pedagogical content knowledge theoretical framework on research on preservice teacher education. Journal of Education, 193(3), 21-27.

Mishra, P., \& Koehler, M. (2006). Technological pedagogical content knowledge: A framework for teacher knowledge. The Teachers College Record, 108(6), 1017-1054.

Mishra, P., Koehler, M. J., \& Kereluik, K. (2009). The song remains the same: Looking back to the future of educational technology. Tech Trends, 53(5), 48-53.

Niess, M. L. (2005). Preparing teachers to teach science and mathematics with technology: Developing a technology pedagogical content knowledge. Teaching and Teacher Education, 21(5), 509-523.

Norris, C., Sullivan, T., \& Poirot, J. (2003). No access, no use, no impact: Snapshot surveys of educational technology in K-12. Journal of Research on Technology in Education, 36(1), 15-27.

Parette, H., \& Blum, C. (2013). Instructional technology in early childhood: Teaching in the digital age. Baltimore, MD: Brookes.

Pierson, M. E. (2001). Technology integration practice as a function of pedagogical expertise. Journal of Research on Computing in Education, 33(4), 413-430.

Piskurich, M. G., (2006). What Is This Instructional Design Stuff Anyway? In G.M. Piskurich (Ed.), Rapid instructional design: Learning ID fast and right (2nd ed.), (pp 2-13). San Francisco, CA: John Wiley \& Sons. 
Renkl, A. (2005). The worked-out examples principle in multimedia learning. In R. E. Mayer (Ed.), Handbook of multimedia learning (pp. 229-246). Cambridge: Cambridge University Press.

Richard, V. E. (2009). A Guide to integrating COTS Games into Your Classroom. In V. E. Richard (Ed.), Handbook of research on effective electronic gaming in education (pp. 179-199). doi: 10.4018/978-1-59904-808-6.ch011

Saravanan, T., \& Nagadeeps, N. (2017). Impact of information communication and technology integration on stress \& cognitive load. International Journal of Pure and Applied Mathematics, 116(10), 349-359.

Shirvani, H. (2014). Pre-service teachers' attitudes toward using technology in schools. Journal of Literacy and Technology, 15(1), 33-53.

Shulman, L. S. (1986). Those who understand: Knowledge growth in teaching. Educational Researcher, 15(2), 4-14.

Smith, H. J., Higgins, S., Wall, K. \& Miller, J. (2005). Interactive whiteboards: Boon or bandwagon? A critical review of the literature. Journal of Computer Assisted Learning, 21(2), 91-101.

Smith, P.L., \& Ragan, T.J. (2005). Instructional design (3rd ed.). Hoboken, NJ: John Wiley \& Sons, Inc.

Stuart, C., \& Thurlow, D. (2000). Making it their own: Preservice teachers' experiences, beliefs, and classroom practices. Journal of Teacher Education, 51(2), 113-121.

Taylor, M., Harlow, A. \& Forret, M. (2010). Using a computer programming environment and an interactive whiteboard to investigate some mathematical thinking. Procedia Social and Behavioral Science, 8, 561-570.

Tabbers, H. K., Martens, R. L., \& van Merriënboer, J. J. (2000). Multimedia instructions and cognitive load theory: Split-attention and modality effects. Paper presented at the Association for Educational Communications and Technology 2000, Long Beach, CA. Abstract retrieved on September 27, 2016, from https://www.ou.n1/Docs/Expertise/ OTEC/Publicaties/huib\%20tabbers/AEC T2000\%20Huib\%20Tabbers.pdf

Tearle, P., \& Golder, G. (2008). The use of ICT in the teaching and learning of physical education in compulsory education: How do we prepare the workforce of the future? European Journal of Teacher Education, 31(1), 55-72.

Tsai, C. C., \& Chai, C. S. (2012). The" third"-order barrier for technology-integration instruction: Implications for teacher education. Australasian Journal of Educational Technology, 28(6), 1057 1060.

Tondeur, J., Pareja Roblin, N., van Braak, J., Voogt, J., \& Prestridge, S. (2017). Preparing beginning teachers for technology integration in education: ready for take-off? Technology, Pedagogy and Education, 26(2), 157-177.

Tondeur, J., van Braak, J., Sang, G., Voogt, J., Fisser, P., \& Ottenbreit-Leftwich, A. (2012). Preparing pre-service teachers to integrate technology in education: A synthesis of qualitative evidence. Computers and Education, 59(1), 134-144.

UNESCO. (2008). ICT competency standards for teachers: Competency standards modules. Retrieved on March 22, 2016, from http://unesdoc .unesco.org/images/0015/001562/156210E.pdf

U.S. Department of Education. (2002). Technology in schools: Suggestions, tools, and guidelines for assessing technology in elementary and secondary education. Retrieved on April 14, 2016, from http://nces.ed.gov/pubs2003/ tech_schools/index.asp

Van Gog, T., Kester, L., \& Paas, F. (2011). Effects of worked examples, example-problem, and problem-example pairs on novices' learning. 
Contemporary Educational Psychology, 36(3), 212-218.

Van Merrienboer, J. J. G., \& Sweller, J. (2005). Cognitive load theory and complex learning: Recent developments and future directions. Educational Psychology Review, 17(2), 147-177.

Wagle, M. P. (2013). Integrate ICT into education system. Retrieved on September 5, 2016, from https://thehimalayantimes.com/kathmandu /integrate-ict-education-system/

Wang, L., Ertmer, P. A., \& Newby, T. J. (2004). Increasing preservice teachers' self-efficacy beliefs for technology integration. Journal of Research on Technology in Education, 36(3), 231-250. doi: http://dx.doi.org/10.1080/ 15391523.2004.10782414

Wood, D., Bruner, J. S., \& Ross, G. (1976). The role of tutoring in problem solving. Journal of Child Psychology and Psychiatry, 17(2), 89-100.

Yelland, N. (2005). Curriculum, pedagogies and practice with ICT in the information age. In N. Yelland (Ed.), Critical Issues in Early Childhood Education (pp. 224-242). UK: Open University Press. 


\section{Appendix A}

COPYRIGHT @ JIWAKRAJ BAJRACHARYA, 2018

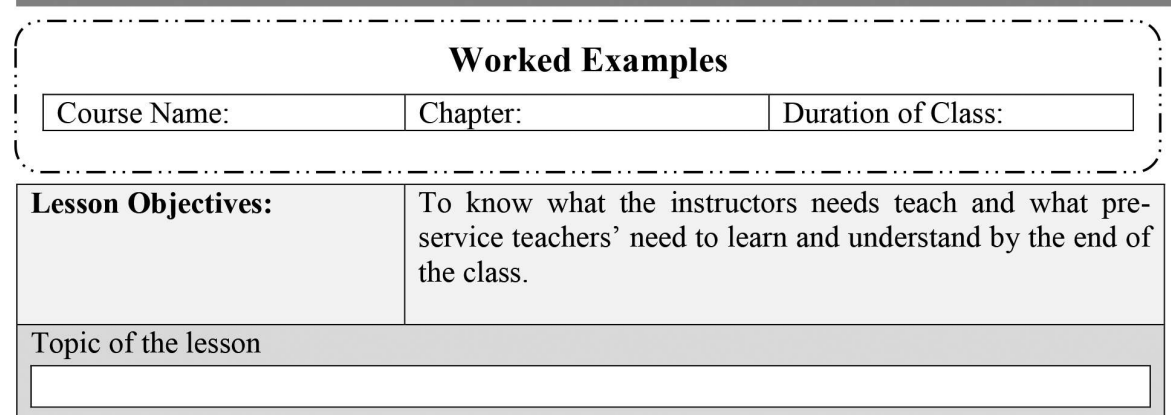

Pre-service teachers need to learn

Pre-service teachers need to understand/ be able to do at the end of class

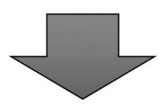

STEP 1

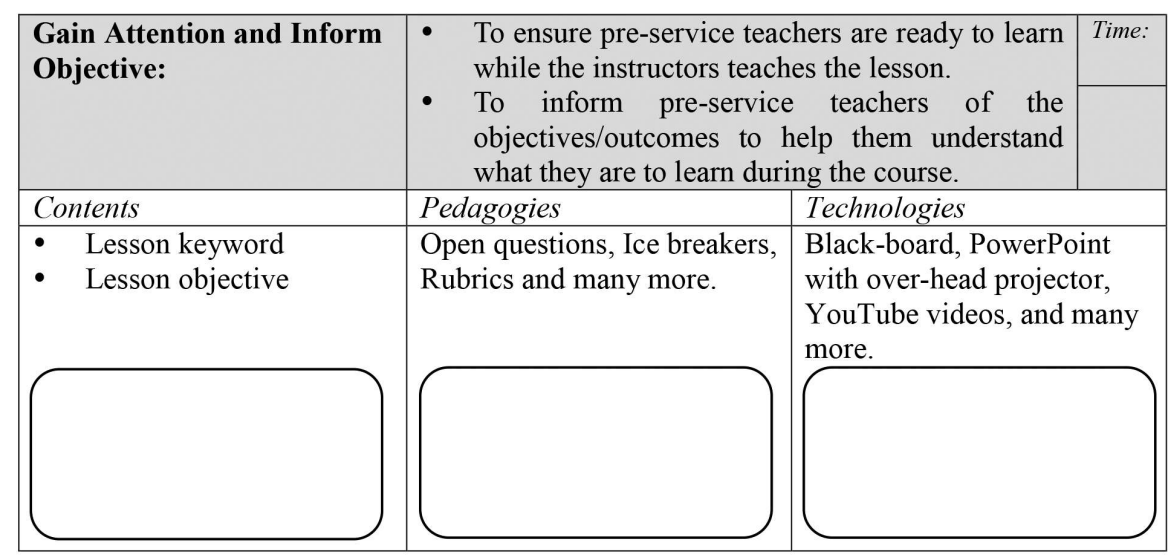




\section{STEP 2}

\begin{tabular}{|c|c|c|c|}
\hline $\begin{array}{l}\text { Recall and Present the } \\
\text { Content: }\end{array}$ & $\begin{array}{l}\text { To help pre-service teach } \\
\text { information by relating } \\
\text { already know or to some } \\
\text { experienced. } \\
\text { - To present the content eff }\end{array}$ & $\begin{array}{l}\text { is make sense of new } \\
\text { i to something they } \\
\text { ing they have already } \\
\text { tively. }\end{array}$ & Time: \\
\hline Contents & Pedagogies & Technologies & \\
\hline $\begin{array}{ll}\text { - } & \text { Preservice teachers' } \\
\text { previous } \\
\text { experiences/concepts } \\
\text { Organize and chunk } \\
\text { content in meaningful } \\
\text { way } \\
\text { - Provide examples }\end{array}$ & $\begin{array}{l}\text { Demonstration, Readings, } \\
\text { Web discussion, Discussion, } \\
\text { Lecture, Game, Peer work, } \\
\text { Quizzes and many more. }\end{array}$ & $\begin{array}{l}\text { Mobile phones, VCD, } \\
\text { PowerPoint with over- } \\
\text { projector, YouTube vi } \\
\text { social network and ma } \\
\text { more. }\end{array}$ & $\begin{array}{l}\text { head } \\
\text { deos, } \\
\text { ny }\end{array}$ \\
\hline
\end{tabular}

\section{STEP 3}

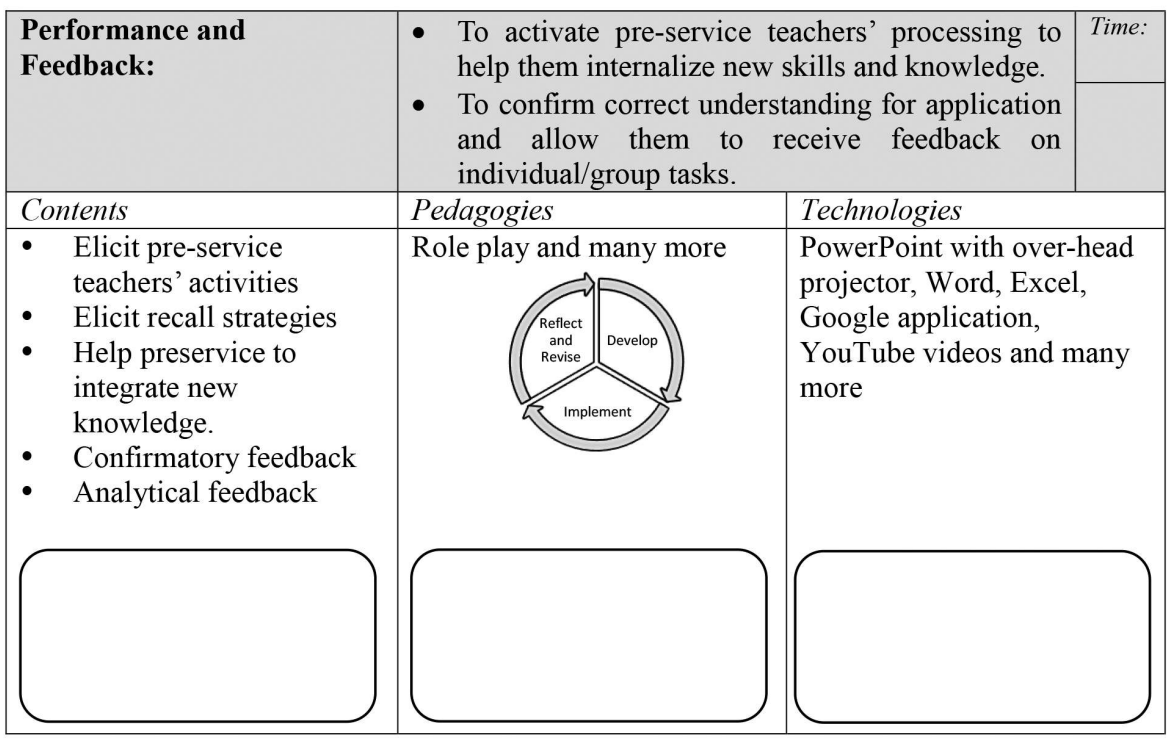




\section{STEP 4}

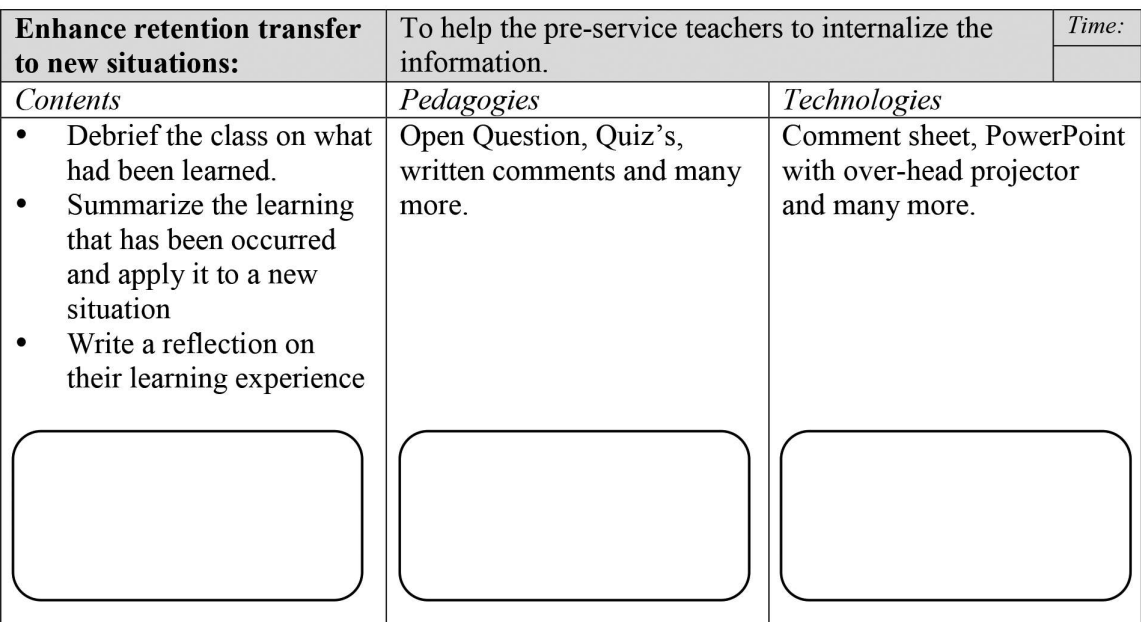

